CENDEKIA, Vol. 12, No. 1, April 2018

p ISSN: 1978 2098; e ISSN: 2407 8557

Http://cendekia.pusatbahasa.or.id; Email: cendekiaoslo@gmail.com

Center of Language and Culture Studies, Surakarta, Indonesia

Apandi. 2018. Pengaruh Gaya Kepemimpinan dan Motivasi terhadap Kinerja Pegawai pada Biro Umum dan Keuangan Universitas Lampung.

Cendekia, (2018), 12(1): 61 74. DOI: 10.30957/Cendekia.v12i1.463.

\title{
PENGARUH GAYA KEPEMIMPINAN DAN MOTIVASI TERHADAP KINERJA PEGAWAI PADA BIRO UMUM DAN KEUANGAN UNIVERSITAS LAMPUNG
}

\author{
Apandi \\ Program Studi Ilmu Administrasi \\ Fakultas Ilmu Sosial dan Ilmu Politik \\ Universitas Lampung \\ Email: apandi.ad@gmail.com
}

\begin{abstract}
This correlational study aims at seeing the effect of leadership style and motivation towards employee performance. A number of 53 sample was selected from General and Finance Bureau at Lampung University. Data were collected using questionnaire and were analyzed using multiple linier regression with the help of SPSS 17.0 statistical software. Result of hypothesis testing shows $\mathrm{t}$-value $=2.374$ and $\mathrm{t}$-table $=1.67655$. In addition, for the motivation variable on employee performance reveals $\mathrm{t}$-value $=7.283$ and $\mathrm{t}$-table $=1.67655$. The simultaneous testing altogether obtained statistical results of F-value for 40.288 and F-table $=3.18$. The evidence means that there is a significant effect either partially or simultaneously between the leadership style and motivation on employee performance of the General and Finance Bureau of Lampung University.
\end{abstract}

Keywords: leadership style, motivation, finance, bureau.

DOI: 10.30957/Cendekia.v12i1.463.

\section{PENDAHULUAN}

Perkembangan organisasi perguruan tinggi dewasa ini tumbuh dan berkembang dengan sangat dinamis. Perkembangan tersebut memerlukan sistem manajemen yang efektif yang dapat dengan mudah menyesuaikan diri dan dapat mengakomodasikan setiap perubahan baik yang sedang dan telah terjadi. Dengan demikian, organisasi sudah tidak lagi dipandang sebagai sistem tertutup tetapi organisasi merupakan sistem terbuka yang harus merespon dan mengakomodasikan berbagai perubahan ekternal dengan cepat dan efisien.

Penyelenggaraan manajemen di perguruan tinggi tidak hanya ditentukan oleh infrastruktur dan fasilitas yang memadai serta dukungan dana semata, tetapi juga ditentukan dari keberhasilan dalam mengelola sumber daya manusia. Manajemen sumber daya manusia merupakan serangkaian tindakan mulai dari sistem seleksi, pengembangan karir, pendidikan dan latihan, dan proses penyiapan personel untuk menduduki jabatan yang lebih tinggi. Dengan demikian, masalah sumber daya manusia merupakan masalah yang kompleks bagi organisasi (Sutrisno, 2013). 
CENDEKIA, Vol. 12, No. 1, April 2018

p ISSN: 1978 2098; e ISSN: 2407 8557

Http://cendekia.pusatbahasa.or.id; Email: cendekiaoslo@gmail.com

Center of Language and Culture Studies, Surakarta, Indonesia

Apandi. 2018. Pengaruh Gaya Kepemimpinan dan Motivasi terhadap Kinerja Pegawai pada Biro Umum dan Keuangan Universitas Lampung.

Cendekia, (2018), 12(1): 61 74. DOI: 10.30957/Cendekia.v12i1.463.

Manajemen kepegawaian dan sumberdaya manusia sangat penting bagi organisasi dalam mengelola, mengatur, dan memanfaatkan pegawai sehingga dapat berfungsi secara produktif untuk tercapainya tujuan organisasi (Mangkunegara, 2011:1). Masalah yang ada dalam manajemen sumber daya manusia, merupakan masalah yang patut mendapat perhatian setiap organisasi adalah masalah kinerja pegawai, karena kinerja pegawai sangat mempengaruhi keberhasilan suatu organisasi.

Salah satu unit kerja di lingkungan Universitas Lampung yang memiliki peran memberikan layanan adalah Biro Umum dan Keuangan Universitas Lampung selaku unsur pelaksana administrasi yang menyelenggarakan pelayanan teknis dan administratif kepada seluruh unsur di lingkungan Unila, serta mempunyai tugas melaksanakan urusan keuangan, kepegawaian, ketatausahaan, kerumahtanggaan, hukum, ketatalaksanaan, dan pengelolaan barang milik negara, dituntut mampu memiliki kinerja yang baik dalam memberikan pelayanan yang optimal kepada mahasiswa, masyarakat kampus dan stakeholder secara efektif dan efisien.

Pelaksanaan layanan dan adminsitrasi yang berlangsung di Biro Umum dan Keuangan Universitas Lampung diperankan oleh tenaga kependidikan, dimana tenaga kependidikan adalah anggota masyarakat yang mengabdikan diri dan diangkat untuk menunjang penyelenggaraan pendidikan tinggi, jadi tenaga kependidikan di Universitas Lampung adalah para Pegawai Negeri Sipil (PNS) bagian administrasi atau struktural.

Berdasarkan prasurvai peneliti dengan melihat kondisi kerja yang terjadi diduga adanya indikasi rendahnya kinerja dapat dilihat masih terjadinya keterlambatan dalam pengurusan atau penyelesaian suatu berkas, pegawai tidak berada ditempat kerjanya, dan kurang cepatnya pelayanan yang diberikan pegawai. Hal ini merupakan indikasi masih kurangnya motivasi mereka bekerja dengan adanya fenomena tersebut dimana para pegawai cenderung mengalami penurunankinerja.Selanjutnya data dalam Rencana Strategis (Renstra) Universitas Lampung Tahun 2011-2015 jumlah tenaga kependidikan di Unila pada tahun 2011 sebanyak 741 orang, jumlah ini masih belum ideal untuk melayani dosen dan mahasiswa dengan tingkat perbandingan sebesar 1:27. Hal ini akan berpengaruh pada kualitas layanan yang diberikan. Selanjutnya Tingkat pertumbuhan tenaga kependidikan selama 5 tahun (2007-2011) juga mengalami penurunan rata-rata sebesar 12,5\%. (Renstra Unila Tahun 2011-2015). Dari data di atas, maka dapat dilihat bahwa jumlah tenaga kependidikan, rasionya masih belum cukup untuk melayani mahasiswa dan dosen sebagai pelanggan utama.

Untuk mewujudkan kinerja organisasi yang optimal, salah satunya adalah dengan mengoptimalkan sumber manusia yang ada, menggerakkan, memberikan motivasi atau dorongan, berkoordinasi dan berkomunikasi kepada staf sehingga diharapkan akan tercipta suasana dan hubungan kerja yang baik. Salah satu permasalahan pokok dalam setiap organisasi ialah bagaimana memberi motivasi kepada bawahan untuk melakukan pekerjaan dengan baik. Pemimpin harus dapat memahami perilaku bawahan, artinya seorang pemimpin dalam tugas keseluruhan hendaknya dapat memperhatikan, mengamati perilaku para bawahan masing-masing, dengan memahami perilaku mereka akan lebih memudahkan tugasnya memberikan 
CENDEKIA, Vol. 12, No. 1, April 2018

p ISSN: 1978 2098; e ISSN: 2407 8557

Http://cendekia.pusatbahasa.or.id; Email: cendekiaoslo@gmail.com

Center of Language and Culture Studies, Surakarta, Indonesia

Apandi. 2018. Pengaruh Gaya Kepemimpinan dan Motivasi terhadap Kinerja Pegawai

pada Biro Umum dan Keuangan Universitas Lampung.

Cendekia, (2018), 12(1): 61 74. DOI: 10.30957/Cendekia.v12i1.463.

motivasi.

Berdasarkan observasi peneliti, rendahnya motivasi pegawai dalam melakukan kerjanya dapat dilihat dari tingginya tingkat ketidakdisiplinan pegawai, seperti terlihat ketika jam kerja tidak berada ditempat, tidak mampu menyelesaikan tugas dengan tepat waktu, dan kurang bergairah dalam bekerja. Hal-hal tersebut tentunya akan mempengaruhi kinerja pegawai dalam memberikan pelayanan.

Penelitian yang dilakukan oleh Historika (2012) menyimpulkan bahwa bahwa Gaya Kepemimpinan secara parsial berpengaruh terhadap Kinerja Pegawai dengan pengaruh sebesar 28,6\%. Berdasarkan hasil analisis menyimpulkan bahwa gaya kepemimpinan berpengaruh positif terhadap kinerja pegawainya, dan motivasi kerja secara parsial berpengaruh terhadap kinerja pegawai dengan pengaruh sebesar $11,9 \%$. Berdasarkan hasil analisis menyimpulkan bahwa motivasi kerja berpengaruh positif terhadap kinerja pegawainya. Selanjutnya berdasarkan hasil analisis secara simultan dengan menggunakan menyimpulkan bahwa gaya kepemimpinan dan motivasi kerja pegawai berpengaruh $28,7 \%$ berpengaruh positif dalam menghasilkan kinerja pegawai yang ada.

Penelitian yang dilakukan oleh Yusmalinda (2012) menyimpulkan bahwa motivasi dan gaya kepemimpinan secara parsial berpengruh positif dan signifikan terhadap kinerja pegawai, memperlihatkan bahwa setiap peningkatan motivasi akan meningkatkan kinerja pegawai, begitu pula dengan gaya kepemimpinan yang sesuai dengan harapan pegawai akan meningkatkan kinerja pegawai. Selanjutnya motivasi dan gaya kepemimpinan secara simultan berpengaruh positif dan signifikan terhadap kinerja pegawai dengan besarnya pengruh sebesar $24,1 \%$ berarti peningktan motivasi dan penyesuaian gaya kepemimpinan dengan harapan pegawai akan meningkatkan kinerja pegawai Dinas Pendidikan Kabupaten Bungo.

Penelitian yang dilakukan oleh Dwiyanto (2001) menyimpulkan bahwa terdapat hubungan yang positif dan signifikan antara variabel kinerja pegawai dengan variabel gaya kepemimpinan, dengan koefisien korelasi sebesar 0,588 dengan tingkat signifikansi 96,1\%. dan terdapat hubungan yang signifikan antara variabel kinerja pegawai dengan dengan iklim organisasi, dengan koefisien korelasi sebesar 0,457 dengan tingkat signifikansi 98\%. Terdapat hubungan yang signifikansi antar variabel kinerja pegawai dengan variabel motivasi kerja, dengan koefisien korelasi sebesar 0,418 dengan tingkat signifikansi 97,1\%. Selanjutnya besarnya pengaruh variabel gaya kepemimpinan, iklim organisasi dan motivasi kerja pegawai terhadap variabel kinerja pegawai diketahui melalui koefisien determinasi sebesar 0,58 atau 58\%.

Alasan peneliti tertarik dalam penelitian ini pertama ingin mengetahui bagaimana peran pimpinan sangat menentukan dalam memotivasi kinerja pegawai sehingga tujuan biro umum dan keuangan sebagai unsur pelaksanaan administrasi di Unila dalam menyelenggarakan pelayanan teknis dan adminsitratif akan dapat tercapai dengan baik..

Berdasarkan uraian di atas, dan latar belakang masalah maka perlu dilakukan penelitian untuk mengungkapkan pengaruh gaya kepemimpinan dan motivasi terhadap kinerja pegawai pada biro umum dan keuangan Universitas Lampung. 
CENDEKIA, Vol. 12, No. 1, April 2018

p ISSN: 1978 2098; e ISSN: 2407 8557

Http://cendekia.pusatbahasa.or.id; Email: cendekiaoslo@gmail.com

Center of Language and Culture Studies, Surakarta, Indonesia

Apandi. 2018. Pengaruh Gaya Kepemimpinan dan Motivasi terhadap Kinerja Pegawai pada Biro Umum dan Keuangan Universitas Lampung. Cendekia, (2018), 12(1): 61 74. DOI: 10.30957/Cendekia.v12i1.463.

\section{LANDASAN TEORI}

Menurut House dalam Yukl (2009:4) mengatakan bahwa: Kepemimpinan adalah kemampuan individu untuk mempengaruhi, memotivasi, dan membuat orang lain mampu memberikan kontribusinya demi efektivitas dan keberhasilan organisasi. Jadi dari pendapat House dapat dikatakan bahwa kepemimpinan merupakan cara mempengaruhi dan memotivasi orang lain agar orang tersebut mau berkontribusi untuk keberhasilan organisasi.

Sedangkan Terry dalam Wahjosumidjo (1994:25) menyatakan bahwa "Leadership is the activity of infuencing exercised to strive willingly for group objectives" (Kepemimpinan adalah kegiatan dalam mempengaruhi orang lain untuk bekerja keras dengan penuh kemauan untuk tujuan kelompok). Dari pendapat Terry dapat diartikan bahwa kepemimpinan itu adalah merupakan kemampuan untuk mempengaruhi dan menggerakkan orang lain untuk mencapai tujuan.

Sugandha (1986:1) tugas pimpinan tidak hanya memberi perintah, tetapi mendorong dan memfasilitasi perbaikan mutu pekerjaan yang dilakukan oleh anggota atau bawahan. Selanjutnya menurut Edward Deming dalam Margono Slamet (1999:1) adalah melembagakan kepemimpinan yang membantu setiap orang dalam organisasi untuk dapat melakukan pekerjaan dengan baik melalui kegiatan-kegiatan pembinaan, memfasilitasi, membantu mengatasi kendala, dan lain sebagainya. Upaya suatu organisasi untuk meningkatkan mutu kinerjanya memerlukan adanya kepemimpinan yang selalu memotivasi anggota-anggota lain dari organisasi itu untuk selalu memperbaiki mutu kerjanya.

Berdasarkan definisi kepemimpinan di atas dapat diartikan bahwa kepemimpinan adalah kemampuan seseorang dalam mempengaruhi, menggerakkan, mendorong, mengendalikan orang lain atau bawahannya untuk melakukan sesuatu pekerjaan atas kesadarannya dan berkontribusi dalam mencapai suatu tujuan.

Menurut Thoha (2013:49) bahwa gaya kepemimpinan merupakan norma perilaku yang digunakan oleh seseorang pada saat orang tersebut mencoba mempengaruhi perilaku orang lain seperti yang ia lihat.

Sedangkan Rivai (2014:42) menyatakan gaya kepemimpinan adalah sekumpulan ciri yang digunakan pimpinan untuk memengaruhi bawahan agar sasaran organisasi tercapai atau dapat pula dikatakan bahwa gaya kepemimpinan adalah pola perilaku dan strategi yang disukai dan sering diterapkan oleh seorang pemimpin. Gaya kepemimpinan yang menunjukkan, secara langsung maupun tidak langsung, tentang keyakinan seorang pimpinan terhadap kemampuan bawahannya.Artinya gaya kepemimpinan adalah perilaku dan strategi, sebagai hasil kombinasi dari falsafah, keterampilan, sifat, sikap, yang sering diterapkan seorang pemimpin ketika ia mencoba memengaruhi kinerja bawahannya. Selanjutnya menurut Stonner (1996:165) menyatakan bahwa gaya kepemimpinan adalah berbagai pola tingkah laku yang disukai oleh pemimpin dalam proses mengarahkan dan mempengaruhi pekerja.

Salah satu pendekatan kontingensi utama pada kepemimpinan adalah Model Kepemimpinan Situasional yang dikemukakan oleh Paul Hersey dan Kenneth Blanchard, dalam Stonner (1996:171) mengatakan bahwa "Gaya kepemimpinan yang 
CENDEKIA, Vol. 12, No. 1, April 2018

p ISSN: 1978 2098; e ISSN: 2407 8557

Http://cendekia.pusatbahasa.or.id; Email: cendekiaoslo@gmail.com

Center of Language and Culture Studies, Surakarta, Indonesia

Apandi. 2018. Pengaruh Gaya Kepemimpinan dan Motivasi terhadap Kinerja Pegawai pada Biro Umum dan Keuangan Universitas Lampung.

Cendekia, (2018), 12(1): 61 74. DOI: 10.30957/Cendekia.v12i1.463.

paling efektif bervariasi dengan kesiapan karyawan. Hersey dan Blanchard mendifenisikan kesiapan sebagai keinginan untuk berpretasi, kemauan untuk menerima tanggung jawab, dan kemampuan yang berhubungan dengan tugas, keterampilan dan pengalaman. Sasaran dan pengetahuan dari pengikut merupakan variabel penting dalam menentukan gaya kepemimpinan yang efektif.

Menurut Hersey dan Blanchard dikutip oleh Rivai (2014:16) menyatakan bahwa hubungan antara pimpinan dan anggotanya mempunyai empat tahap/fase yang diperlukan bagi pimpinan untuk mengubah gaya kepemimpinan-nya yaitu: Tahap pertama, pada kesiapan awal perhatian pimpinan pada tugas sangat tinggi, anggota diberi instruksi yang jelas dan dibiasakan dengan peraturan, struktur dan prosedur kerja. Tahap kedua adalah di mana anggota sudah mampu menangani tugasnya, perhatian pada tugasnya sangat penting karena bawahan belum dapat bekerja tanpa struktur. Kepercayaan pimpinan pada bawahan semakin meningkat. Tahap ketiga, di mana anggota mempunyai kemampuan lebih besar dan motivasi berprestasi mulai tampak dan mereka secara aktif mencari tanggung jawab yang lebih besar, pemimpin masih harus mendukung dan memberikan perhatian, tetapi tidak perlu lagi memberikan pengarahan. Tahap keempat adalah tahap di mana anggota mulai percaya diri, dapat mengarahkan diri dan pengalaman, pemimpin dapat mengurangi jumlah perhatian dan pengarahan.

Motivasi berasal dari kata Latin movere yang berarti dorongan atau daya penggerak. Motivasi dalam manajemen hanya ditujukan pada sumber daya manusia umumnya dan bawahan khususnya. Hasibuan (2007:95) mengatakan motivasi adalah pemberian daya penggerak yang menciptakan kegairahan kerja seseorang, agar mereka mau bekerja sama, bekerja efektif dan terintegrasi dengan segala daya upayanya untuk mencapai kepuasan.

Sedangkan menurut Robbins (2002:213) dalam bukunya perilaku organisasi, mendefinisikan Motivasi sebagai proses yang ikut menentukan intensitas, arah, dan ketekunan individu dalam usaha mencapai sasaran. Jadi motivasi merupakan upaya yang ada dalam diri seseorang dalam memenuhi kebutuhannya guna mencapai tujuan organisasi.

Selanjutnya menurut Handoko, (2012:250) motivasi adalah keadaan dalam pribadi seseorang yang mendororng keinginan individu untuk melakukan kegiatankegiatan tertentu guna mencapai tujuan. Jadi motivasi yang ada pada seseorang merupakan kekuatan pendorong yang akan mewujudkan suatu perilaku guna mencapai tujuan kepuasan dirinya.

Istilah kinerja berasal dari kata Job Performance atau Actual Performance yang merupakan prestasi kerja atau prestasi sesungguhnya yang dicapai oleh seseorang. Mangkunegara (2011:67) mengatakan: kinerja adalah hasil kerja secara kualitas dan kuantitas yang dicapai oleh seorang pegawai dalam melaksanakan tugasnya sesuai dengan tanggung jawab yang diberikan kepadanya.

Menurut Ruky (2001:14) menyatakan bahwa kinerja merupakan pengalih bahasaan dari bahasa Inggris performance yang diartikan oleh Bernardin dan Russel mendefinisikan kinerja sebagai pencatatan hasil-hasil yang diperoleh dari fungsi 
CENDEKIA, Vol. 12, No. 1, April 2018

p ISSN: 1978 2098; e ISSN: 2407 8557

Http://cendekia.pusatbahasa.or.id; Email: cendekiaoslo@gmail.com

Center of Language and Culture Studies, Surakarta, Indonesia

Apandi. 2018. Pengaruh Gaya Kepemimpinan dan Motivasi terhadap Kinerja Pegawai pada Biro Umum dan Keuangan Universitas Lampung.

Cendekia, (2018), 12(1): 61 74. DOI: 10.30957/Cendekia.v12i1.463.

pekerjaan atau kegiatan tertentu selama kurun waktu tertentu.

Pendapat lain menurut Gibson dalam Nawawi (2013:213) mengemukakan bahwa kinerja seseorang ditentukan oleh kemampuan dan motivasinya untuk melaksanakan pekerjaan. Selanjutnya dikatakan pelaksanaan pekerjaan ditentukan oleh interaksi kemampuan dan motivasi.

Sedangkan Prawirosentono dalam Sutrisno (2011:170) mengemukakan kinerja adalah hasil kerja dapat dicapai oleh seseorang atau sekelompok orang dalam suatu organisasi, sesuai dengan wewenang dan tanggung jawab masing-masing, dalam

Selanjutnya menurut Hasibuan (2007:94) menjelaskan bahwa kinerja adalah suatu hasil kerja yang dicapai seseorang dalam melaksanakan tugas-tugas yang dibebankan kepadanya yang didasarkan atas kecakapan, pengalaman, dan kesungguhan serta waktu.

Kinerja merupakan suatu gambaran mengenai tingkat pencapaian pelaksanaan suatu kegiatan/program/kebijakan dalam mewujudkan sasaran, tujuan, misi, visi serta organisasi. Pada dasarnya pengertian kinerja berkaitan dengan tanggung jawab individu atau organisasi dalam menjalankan apa yang menjadi wewenang dan tanggung jawab yang diberikan kepadanya.

Dari berbagai definisi kinerja di atas, dapat disimpulkan bahwa Kinerja adalah suatu hasil kerja yang dapat dicapai seseorang atau sekelompok orang dalam suatu organisasi sesuai wewenang dan tanggung jawabnya untuk mencapai tujuan organisasi.

Nawawi (2013:233), mengemukakan bahwa pengukuran kinerja merupakan suatu alat manajemen yang digunakan untuk meningkatkan kualitas pengambilan keputusan dan akuntabilitas. Pengukuran kinerja juga digunakan untuk menilai pencapaian tujuan dan sasaran (goals and objectives).

Selanjutnya menurut Joel G. Siegel dan Jae K. Shim dalam Irham (2011:71) menyatakan performance measurement (pengukuran kinerja) adalah kuantifikasi dari efisiensi perusahaan atau segmen atau keefektifan dalam pengoperasian bisnis selama periode akuntansi. Karena organisasi dijalankan oleh manusia, maka penilaian kinerja sesungguhnya merupakan penilaian atas perilaku manusia dalam melaksanakan peran yang mereka jalankan di dalam organisasi. Tujuan utama penilaian kinerja adalah untuk memotivasi karyawan dalam mencapai sasaranorganisasi dan dalam mematuhi standar perilaku yang telah ditetapkan sebelumnya agar membuahkan tindakan dan hasil yang diinginkan.

Kemudian menurut Handoko (2012:135) mengatakan penilaian prestasi kerja (performance appraisal) adalah proses melalui mana organisasi-organisasi mengevaluasi atau menilai prestasi kerja karyawan. Kegiatan ini dapat memperbaiki keputusan-keputuan personalia dan memberikan umpan balik kepada para karyawan tentang pelaksanaan kerja mereka.

\section{METODE}

Jenis penelitian ini adalah penelitian kuantitatif korelational (Nazir, 1999). Penelitian dilakukan di Biro Umum dan Keuangan Universitas Lampung. Populasi penelitian ini yaitu sebanyak 110 orang, sedangkan sampel penelitian sebanyak 53 
Http://cendekia.pusatbahasa.or.id; Email: cendekiaoslo@gmail.com Center of Language and Culture Studies, Surakarta, Indonesia

Apandi. 2018. Pengaruh Gaya Kepemimpinan dan Motivasi terhadap Kinerja Pegawai pada Biro Umum dan Keuangan Universitas Lampung.

Cendekia, (2018), 12(1): 61 74. DOI: 10.30957/Cendekia.v12i1.463.

orang pegawai. Data dikumpulkan dengan menggunakan angket yang dikembangkan oleh peneliti berdasarkan teori yang ada. Sebelum uji hipotesis dilakukan uji validitas, reliabilitas, dan linieritas yang seluruhnya memenuhi syarat. Data dianalisis menggunakan uji regresi dengan satu prediktor (parsial), maupun regresi dua prediktor ( simultan).

\section{HASIL}

\subsection{Karakteristik Responden}

Hasil penelitian yang dilakukan kepada responden menurut kelompok umur, maka dapat dilihat pada tabel 1.

Tabel. 1 Karakteristik Responden Berdasarkan Kelompok Umur

\begin{tabular}{lccc}
\hline No & Kelompok Umur & Responden & Persentase \\
\hline 1 & $20-29$ & 7 & 13.20 \\
\hline 2 & $30-39$ & 19 & 35.85 \\
\hline 3 & $40-49$ & 15 & 28.30 \\
\hline 4 & 50 tahun ke atas & 12 & 22.64 \\
\hline & Jumlah & $\mathbf{5 3}$ & $\mathbf{1 0 0}$ \\
\hline
\end{tabular}

\section{Sumber : Data Penelitian 2015}

Berdasarkan tabel diatas maka diketahui bahwa sebanyak $7(13,20 \%)$ responden berusia antara 20-29 tahun, sebanyak 19 (35,85\%) responden berusia antara 30-39 tahun, sebanyak $15(28,30 \%)$ responden berusia antara 40-49 tahun, dan sebanyak $12(22,64 \%)$ responden berusia 50 tahun ke atas. Dengan demikian maka sebagaian besar responden dalam penelitian ini berusia antara 30-39 tahun.

Hasil penelitian yang dilakukan kepada responden menurut jenis kelamin, maka dapat dilihat pada tabel 2.

Tabel. 2 Karakteristik Responden Berdasarkan Jenis Kelamin

\begin{tabular}{|l|l|c|c|}
\hline No & Jenis Kelamin & Responden & Persentase \\
\hline 1 & Laki-Laki & 33 & 62.26 \\
\hline 2 & Perempuan & 20 & 37.74 \\
\hline \multicolumn{1}{|c|}{ Jumlah } & $\mathbf{5 3}$ & $\mathbf{1 0 0}$ \\
\hline
\end{tabular}

Sumber : Data Penelitian, 2015 
Http://cendekia.pusatbahasa.or.id; Email: cendekiaoslo@gmail.com Center of Language and Culture Studies, Surakarta, Indonesia

Apandi. 2018. Pengaruh Gaya Kepemimpinan dan Motivasi terhadap Kinerja Pegawai pada Biro Umum dan Keuangan Universitas Lampung. Cendekia, (2018), 12(1): 61 74. DOI: 10.30957/Cendekia.v12i1.463.

Hasil penelitian menurut pendidikan terakhir dapat dilihat pada tabel 3. Data pada tabel 3 menunjukkan bahwa $4(7,57 \%)$ responden berpendidikan SMA 16 (30,18\%) SMA sederajat, 13 (24,52\%) Diploma, 15 (28,30\%) Sarjana, dan $5(9,43 \%)$ Magister.

Tabel. 3 Karakteristik Responden Berdasarkan Pendidikan Terakhir

\begin{tabular}{|l|l|c|c|}
\hline No & \multicolumn{1}{|c|}{ Pendidikan Terakhir } & Responden & Persentase \\
\hline 1 & Sekolah Menengah Pertama dan Sederajat & 4 & 7.57 \\
\hline 2 & Sekolah Menengah Atas dan Sederajat & 16 & 30.18 \\
\hline 3 & Diploma I - III & 13 & 24.52 \\
\hline 4 & Sarjana (Strata I) & 15 & 28.30 \\
\hline 5 & Magister (Strata II) & 5 & 9.43 \\
\hline & Jumlah & $\mathbf{5 3}$ & $\mathbf{1 0 0}$ \\
\hline
\end{tabular}

Sumber : Data Penelitian, 2015

Hasil penelitian yang dilakukan kepada responden menurut golongan pegawai negeri sipil dapat dilihat pada tabel 4 .

Tabel. 4 Karakteristik Responden Berdasarkan Golongan

\begin{tabular}{|l|l|c|c|}
\hline No & \multicolumn{1}{|c|}{ Golongan } & Responden & Persentase \\
\hline 1 & Golongan I (satu) & 5 & 9.43 \\
\hline 2 & Golongan II (dua) & 22 & 41.51 \\
\hline 3 & Golongan III (tiga) & 24 & 45.28 \\
\hline 4 & Golongan IV (empat) & 2 & 3.77 \\
\hline & Jumlah & $\mathbf{5 3}$ & $\mathbf{1 0 0}$ \\
\hline
\end{tabular}

Sumber : Data Penelitian, 2015

Berdasarkan tabel diatas maka diketahui bahwa sebanyak $5 \quad(9,43 \%)$ responden golongan I (satu), sebanyak $22(41,51 \%)$ responden golongan II (dua), sebanyak $24(45,28 \%)$ responden golongan III (tiga), dan sebanyak $2(3,77 \%)$ responden golongan IV (empat). Dengan demikian maka sebagaian besar responden 
CENDEKIA, Vol. 12, No. 1, April 2018

p ISSN: 1978 2098; e ISSN: 2407 8557

Http://cendekia.pusatbahasa.or.id; Email: cendekiaoslo@gmail.com

Center of Language and Culture Studies, Surakarta, Indonesia

Apandi. 2018. Pengaruh Gaya Kepemimpinan dan Motivasi terhadap Kinerja Pegawai pada Biro Umum dan Keuangan Universitas Lampung. Cendekia, (2018), 12(1): 61 74. DOI: 10.30957/Cendekia.v12i1.463.

dalam penelitian ini didominasi golongan III (tiga) sebesar 45,28\%.

\section{Uji $\mathbf{R}^{2}$ (Koefisien Determinasi)}

Koefisien Determinasi $\mathrm{R}^{2}$ pada intinya mengukur seberapa jauh kemampuan model dalam menerangkan variasi variabel dependen. Nilai Koefisien Determinasi adalah antara 0 dan 1 . Tabel 5 menunjukkan nilai $\mathrm{R}^{2}$ yang kecil berarti kemampuan variabel-variabel independen dalam menjelaskan variasi variabel dependen amat terbatas.

Tabel 5.

Uji Koefisien Determinasi $\left(\mathbf{R}^{2}\right)$ Gaya Kepemimpinan dan Motivasi terhadap Kinerja Pegawai

\begin{tabular}{|r|r|r|r|}
\hline Model & R & R Square & \multicolumn{1}{|c|}{$\begin{array}{c}\text { Adjusted R } \\
\text { Square }\end{array}$} \\
\hline 1 & $.786^{\mathrm{a}}$ & .617 & .602 \\
\hline
\end{tabular}

Sumber: Data Penelitian, 2015

Berdasarkan hasil perhitungan di atas dapat diketahui nilai $\mathrm{R}$ adalah sebesar 0,786 sehingga secara simultan korelasi Gaya Kepemimpinan dan Motivasi terhadap Kinerja Pegawai termasuk kuat. Adapun nilai $\mathrm{R}^{2}$ (square) sebesar 0,617 artinya Gaya Kepemimpinan dan Motivasi dapat menjelaskan perubahan Kinerja Pegawai sebesar $61,7 \%$, sedangkan $38,3 \%$ dijelaskan oleh variabel lain.

\subsection{Pengaruh Gaya Kepemimpinan terhadap Kinerja Pegawai}

Pengujian hipotesis secara parsial pengaruh Gaya Kepemimpinan terhadap Kinerja Pegawai digunakan rumus Uji t dengan hasil pada tabel 5.57. Hasil Uji thitung diperoleh nilai sebesar 2.734 sedangkan nilai $t_{\text {tabel }}$ untuk $n=53$ pada $\alpha=0,05$ adalah 1.67655. Hasil ini menunjukkan bahwa Gaya Kepemimpinan berpengaruh positif dan signifikan terhadap Kinerja Pegawai dengan hipotesis. Ha $\mathrm{H}_{1}$ : Ada pengaruh signifikan antara Gaya Kepemimpinan terhadap Kinerja Pegawai. Ho1: Tidak ada pengaruh signifikan antara Gaya Kepemimpinan terhadap Kinerja Pegawai. Maka Ha diterima yaitu ada pengaruh yang signifikan antara Gaya Kepemimpinan terhadap Kinerja Pegawai Biro Umum dan Keuangan di Universitas Lampung.

\subsection{Pengaruh Motivasi terhadap Kinerja Pegawai}

Pengujian hipotesis secara parsial pengaruh Motivasi terhadap Kinerja Pegawai digunakan rumus Uji t dengan hasil seperti pada tabel 6. 
CENDEKIA, Vol. 12, No. 1, April 2018

p ISSN: 1978 2098; e ISSN: 2407 8557

Http://cendekia.pusatbahasa.or.id; Email: cendekiaoslo@gmail.com

Center of Language and Culture Studies, Surakarta, Indonesia

Apandi. 2018. Pengaruh Gaya Kepemimpinan dan Motivasi terhadap Kinerja Pegawai pada Biro Umum dan Keuangan Universitas Lampung. Cendekia, (2018), 12(1): 61 74. DOI: 10.30957/Cendekia.v12i1.463.

\begin{tabular}{|l|l|r|r|}
\hline \multicolumn{2}{|c|}{ Model } & t & Sig. \\
\hline 1 & (Constant) & 6.105 & .000 \\
\cline { 2 - 4 } & Gaya Kepemimpinan & 2.734 & .009 \\
\cline { 2 - 4 } & Motivasi & 7.283 & .000 \\
\hline
\end{tabular}

Sumber: Data Penelitian, 2015

Hasil Uji $t_{\text {hitung }}$ diperoleh nilai sebesar 7.283 sedangkan nilai $t_{\text {tabel }}$ untuk $\mathrm{n}=53$ pada $\alpha=0,05$ adalah 1,6725. Hasil ini menunjukkan bahwa Motivasi berpengaruh positif dan signifikan terhadap Kinerja Pegawai dengan hipotesis: $\mathrm{Ha}_{2}$ : Ada pengaruh signifikan antara Motivasi terhadap Kinerja Pegawai. Ho2: Tidak ada pengaruh signifikan antara Motivasi terhadap Kinerja Pegawai. Maka Ha ${ }_{1}$ diterima yaitu Ada pengaruh yang signifikan antara Motivasi terhadap Kinerja Pegawai Tenaga Kependidikan Biro Umum dan Keuangan Universitas Lampung.

\subsection{Pengaruh Gaya Kepemimpinan dan Motivasi terhadap Kinerja Pegawai}

Hasil Uji F untuk menguji pengaruh simultan Gaya Kepemimpinan dan Motivasi terhadap Kinerja Pegawai, diperoleh nilai $F_{\text {hitung }}$ sebesar 40.288 sedangkan $\mathrm{F}_{\text {tabel }}$ dengan $\mathrm{n}=53$, diperoleh $\mathrm{F}_{\text {tabel }}=3.18$. Dengan hipotesis yang diajukan sebagai berikut. Ha3: Ada pengaruh signifikan antara Gaya Kepemimpinan dan Motivasi terhadap Kinerja Pegawai. $\mathrm{Ho}_{3}$ : Tidak ada pengaruh signifikan antara Gaya Kepemimpinan dan Motivasi terhadap Kinerja Pegawai. Dan kriteria pengujian sebagai berikut. Ho diterima bila $F_{\text {hitung }} \leq F_{\text {tabel. }}$ Ho ditolak bila $F_{\text {hitung }} \geq F_{\text {tabel. }}$ Oleh karena $F_{\text {hitung }}$ $\geq \mathrm{F}_{\text {tabel }}$ maka dengan ini Ho ditolak yang berarti Gaya Kepemimpinan dan Motivasi terhadap Kinerja Pegawai memiliki pengaruh yang signifikan. Dengan demikian dari hasil tersebut membuktikan hipotesis yang diajukan yaitu "Ada pengaruh signifikan Gaya Kepemimpinan dan Motivasi terhadap Kinerja Pegawai Biro Umum dan Keuangan di Universitas Lampung" adalah benar terbukti.

\section{BAHASAN}

\subsection{Pengaruh Gaya Kepemimpinan terhadap Kinerja Pegawai}

Berdasarkan hasil pengujian regresi linear berganda ditemukan hasil pengujian arah regresi antara Gaya Kepemimpinan terhadap Kinerja Pegawai sebesar 0.229 dan nilai konstanta sebesar 26.461 hal ini yang berarti bahwa jika nilai Gaya Kepemimpinan sama sama dinaikan sebesar satu satuan maka akan mengakibatkan peningkatan Kinerja Pegawai sebesar 0.229 begitu juga sebaliknya, hal ini dapat diartikan bahwa pengaruh antara Gaya Kepemimpinan dan Kinerja Pegawai memiliki arah yang berbanding lurus.

Pada pengujian parsial atau uji $\mathrm{t}$ ditemukan hasil hubungan antara Gaya 
CENDEKIA, Vol. 12, No. 1, April 2018

p ISSN: 1978 2098; e ISSN: 2407 8557

Http://cendekia.pusatbahasa.or.id; Email: cendekiaoslo@gmail.com

Center of Language and Culture Studies, Surakarta, Indonesia

Apandi. 2018. Pengaruh Gaya Kepemimpinan dan Motivasi terhadap Kinerja Pegawai pada Biro Umum dan Keuangan Universitas Lampung.

Cendekia, (2018), 12(1): 61 74. DOI: 10.30957/Cendekia.v12i1.463.

Kepemimpinan terhadap Kinerja Pegawai pada Biro Umum dan Keuangan Universitas Lampung sebesar 2.734 dan nilai $t_{\text {tabel }}$ sebesar 1.67655. dengan ini dapat dijelaskan bahwa nilai thitung $(2.734)>t_{\text {tabel }}(1.67655)$ dan pengaruh di antara keduanya dapat dikatakan signifikan. Hal ini tentunya dapat diperkuat berdasarkan hasil jawaban responden mengenai Gaya Kepemimpinan salah satunya adalah "Pimpinan memuji dan menghargai pegawai yang bekerja tepat waktu", hal ini mengindikasikan bahwa gaya pimpinan sangat disegani oleh pegawai dikarenakan mereka selalu mengapresiasi kinerja pegawai yang bekerja tepat pada waktunya.

Menurut Rivai (2014:42) menyatakan gaya kepemimpinan adalah sekumpulan ciri yang digunakan pimpinan untuk memengaruhi bawahan agar sasaran organisasi tercapai atau dapat pula dikatakan bahwa gaya kepemimpinan adalah pola perilaku dan strategi yang disukai dan sering diterapkan oleh seorang pemimpin. Gaya kepemimpinan yang menunjukkan, secara langsung maupun tidak langsung, tentang keyakinan seorang pimpinan terhadap kemampuan bawahannya. Artinya gaya kepemimpinan adalah perilaku dan strategi, sebagai hasil kombinasi dari falsafah, keterampilan, sifat, sikap, yang sering diterapkan seorang pemimpin ketika ia mencoba memengaruhi kinerja bawahannya. Selanjutnya menurut Stonner (1996:165) menyatakan bahwa gaya kepemimpinan adalah berbagai pola tingkah laku yang disukai oleh pemimpin dalam proses mengarahkan dan mempengaruhi pekerja.

Gaya kepemimpinan menurut Hasibuan (2007) maka objek penelitian ini lebih cocok digunakan Gaya Kepemimpinan Partisipatif yaitu apabila dalam kepemimpinannya dilakukan dengan cara persuasif, menciptakan kerja sama yang serasi, menumbuhkan loyalitas, dan partisipasi para bawahan. Pemimpin memotivasi bawahan agar merasa ikut memiliki organisai/instansi. Bawahan harus berpartisipasi memberikan saran, ide, dan pertimbangan dalam proses pengambilan keputusan. Pemimpin dengan gaya partisipatif akan mendorong kemampuan bawahan mengambil keputusan. Dengan demikian, pimpinan akan selalu membina bawahan untuk menerima tanggung jawab yang lebih besar.

Kinerja merupakan suatu kondisi yang harus diketahui dan dikonfirmasikan kepada pihak tertentu untuk mengetahui tingkat pencapaian hasil suatu instansi dihubungkan dengan visi yang diemban suatu organisasi atau perusahaan serta mengetahui dampak positif dan negatif dari suatu kebijakan operasional. Pengukuran kinerja merupakan suatu langkah yang harus dilakukan dalam upaya meningkatkan kinerja organisasi. Melalui pengukuran kinerja tingkat capaian

\subsection{Pengaruh Motivasi terhadap Kinerja Pegawai}

Berdasarkan hasil pengujian regresi linear berganda diatas ditemukan hasil pengujian arah regresi antara Motivasi terhadap Kinerja Pegawai sebesar 0.465 dan nilai konstanta sebesar 26.461 hal ini yang berarti bahwa jika nilai Motivasi Kerja bersama dinaikkan sebesar satu satuan maka akan mengakibatkan peningkatan Kinerja Pegawai sebesar 0.465 begitu juga sebaliknya, hal ini dapat diartikan bahwa pengaruh antara Motivasi Kerja dan Kinerja Pegawai memiliki arah yang berbanding lurus. 
CENDEKIA, Vol. 12, No. 1, April 2018

p ISSN: 1978 2098; e ISSN: 2407 8557

Http://cendekia.pusatbahasa.or.id; Email: cendekiaoslo@gmail.com

Center of Language and Culture Studies, Surakarta, Indonesia

Apandi. 2018. Pengaruh Gaya Kepemimpinan dan Motivasi terhadap Kinerja Pegawai pada Biro Umum dan Keuangan Universitas Lampung.

Cendekia, (2018), 12(1): 61 74. DOI: 10.30957/Cendekia.v12i1.463.

Pada pengujian parsial atau uji t ditemukan hasil hubungan antara Motivasi Kerja terhadap Kinerja Pegawai pada Biro Umum dan Keuangan Universitas Lampung sebesar 7.283 dan nilai $t_{\text {tabel }}$ sebesar 1.67655. dengan ini dapat dijelaskan bahwa nilai $t_{\text {hitung }}(7.283)>t_{\text {tabel }}(1.67655)$ dan pengaruh diantara keduanya dapat dikatakan signifikan. Hal ini tentunya dapat diperkuat berdasarkan hasil jawaban responden mengenai Motivasi Kerja salah satunya adalah "Pimpinan saudara menghargai setiap hasil kerja yang saudara lakukan". Pimpinan tidak segan-segan menghargai setiap hasil kerja yang dilakukan pegawai, hal tersebutlah yang semakin memotivasi pegawai untuk meningkatkan kinerja mereka.

Motivasi merupakan kekuatan pendorong yang akan mewujudkan suatu perilaku guna mencapai tujuan kepuasan dirinya. Motivasi terbentuk dari sikap seseorang pegawai dalam menghadapi situasi kerja. Motivasi merupakan kondisi yang menggerakkan diri pegawai yang terarah untuk mencapai tujuan organisasi, sikap mental merupakan kondisi mental yang mendorong diri pegawai untuk berusaha mencapai prestasi kerja secara maksimal. Penelitian ini lebih cocok Jika dikaitkan dengan teori kepuasan yang dikemukakan Hasibuan (2007). Teori ini mendasarkan pendekatan atas faktor-faktor kebutuhan dan kepuasan individu yang menyebabkannya bertindak dan berperilaku dengan cara tertentu.

Teori ini memusatkan perhatian pada faktor-faktor dalam diri seseorang yang menguatkan, mengarahkan, mendukung dan menghentikan perilakunya. Teori ini mencoba menjawab pertanyaan kebutuhan apa yang memuaskan dan mendorong semangat bekerja seseorang. Hal yang memotivasi semangat bekerja seseorang adalah untuk memenuhi kebutuhan dan kepuasan materiil maupun nonmateriil yang diperolehnya dari hasil pekerjaannya.

Dari deskripsi fakta dilapangan dan dengan data-data di atas, menunjukan bahwa Kepala Biro Umum dan Keuangan Universitas Lampung memiliki gaya kepemimpinan situasional. Model kepemimpinan sangat baik untuk dilaksanakan pada Biro Umum dan Keuangan Universitas Lampung karena karakteristik situasi atau keadaan sebagai faktor penentu utama yang membuat seseorang pemimpin berhasil melaksanakan tugas-tugas organisasi secara efektif dan efisien. Juga gaya ini membahas aspek kepemimpinan lebih mendasar watak kepribadian pemimpin. Gaya ini menyatakan bahwa faktor situasi lebih menentukan keberhasilan seorang pimpinan dibandingkan dengan watak pribadinya. Gaya kepemimpinan situasional berasumsi bahwa situasi yang berbeda membutuhkan tipe kepemimpinan yang berbeda pula.

Menurut Sutikno (2014) dalam mengembangkan gaya kepemimpinan situasional efektif dengan memadukan tingkat kematangan anak buah dengan pola perilaku yang dimiliki pimpinannya. Untuk kematangan para bawahannya agar bekerja sesuai yang dinginkan, maka peneliti merekomendasikan agar Kepala Biro Umum dan Keuangan Universitas Lampung harus menerapkan 4 (empat) gaya yang efektif untuk diterapkan yaitu:

1. Pemimpin memberi instruksi dan mengawasi pelaksanaan tugas dan kinerja anak buahnya.

2. Pemimpin menjelaskan keputusannya dan membuka kesempatan untuk bertanya 
CENDEKIA, Vol. 12, No. 1, April 2018

p ISSN: 1978 2098; e ISSN: 2407 8557

Http://cendekia.pusatbahasa.or.id; Email: cendekiaoslo@gmail.com

Center of Language and Culture Studies, Surakarta, Indonesia

Apandi. 2018. Pengaruh Gaya Kepemimpinan dan Motivasi terhadap Kinerja Pegawai pada Biro Umum dan Keuangan Universitas Lampung.

Cendekia, (2018), 12(1): 61 74. DOI: 10.30957/Cendekia.v12i1.463.

bila kurang jelas.

3. Pemimpin memberi kesempatan untuk menyampaikan ide-ide sebagai dasar pengambilan keputusan.

4. Pemimpin melimpahkan keputusan dan pelaksanaan tugas kepada bawahannya.

Dengan demikian dimensi gaya kepemimpinan yang digunakan dalam gaya ini adalah perilaku pimpinan yang berkaitan dengan tugas kepemimpinannya dan hubungan atasan-bawahan.

\section{SIMPULAN DAN SARAN}

Berdasarkan hasil penelitian dapat disimpulkan:

1. Terdapat pengaruh yang signifikan antara Gaya Kepemimpinan $\left(\mathrm{X}_{1}\right)$ terhadap Kinerja Pegawai (Y) pada Biro Umum dan Keuangandi Universitas Lampung

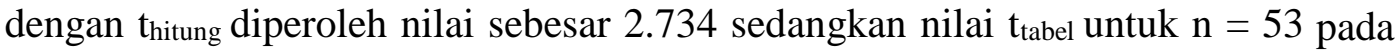
$\alpha=0,05$ adalah 1.67655. Hasil ini menunjukkan bahwa Gaya Kepemimpinan berpengaruh positif dan signifikan terhadap Kinerja Pegawai.

2. Terdapat pengaruh yang signifikan antara Motivasi $\left(X_{2}\right)$ terhadap Kinerja Pegawai (Y) pada Biro Umum dan Keuangan di Universitas Lampung. Uji thitung diperoleh nilai sebesar 7.283 sedangkan nilai tabel untuk $\mathrm{n}=53$ pada $\alpha=0,05$ adalah 1,6725. Hasil ini menunjukkan bahwa Motivasi berpengaruh positif dan signifikan terhadap Kinerja Pegawai.

3. Terdapat pengaruh yang signifikan antara Gaya Kepemimpinan $\left(\mathrm{X}_{1}\right)$ dan Motivasi $\left(\mathrm{X}_{2}\right)$ terhadap Kinerja Pegawai $(\mathrm{Y})$ pada Tenaga Kependidikan di Biro Umum dan Keuangan Universitas Lampung. Diperoleh nilai $F_{\text {hitung }}$ sebesar 40.288 sedangkan $\mathrm{F}_{\text {tabel }}$ dengan $\mathrm{n}=53$, diperoleh $\mathrm{F}_{\text {tabel }}=3.18$.

Adapun saran yang bisa disampaikan ialah:

1. Diharapkan kedepannya untuk para pimpinan pada Biro Umum dan Keuangan Universitas Lampung mampu meningkatkan serta menyesuaikan Gaya Kepemimpinan yang disegani Karyawan demi meningkatkan baik dari segi Produktifitas maupun Kinerja Pegawai pada Biro Umum dan Keuangan Universitas Lampung.

2. Para pimpinan untuk memberikan pembagian tugas dan tanggung jawab kepada pegawai sesuai dengan kemampuan yang dimiliki serta sesuai dengan uraian tugas dan SOP yang berlaku.

3. Untuk penelitian selanjutnya, dapat mengembangkan ruang lingkup variabel lainnya terkait kinerja pegawai seperti pemberian reward, punishment, dan lingkungan kerja. Karena keterbatasan waktu peneliti belum mampu mengembangkan variabel tersebut.

\section{DAFTAR PUSTAKA}

Dwiyanto, 2001, Pengaruh Gaya Kepemimpinan, Iklim Organisasi dan Motivasi Kerja Terhadap Kinerja Pegawai Di Sekretariat Daerah Kabupaten Kendal, Tesis Magister Administrasi Publik Universitas Diponegoro, Semarang. 
CENDEKIA, Vol. 12, No. 1, April 2018

p ISSN: 1978 2098; e ISSN: 2407 8557

Http://cendekia.pusatbahasa.or.id; Email: cendekiaoslo@gmail.com

Center of Language and Culture Studies, Surakarta, Indonesia

Apandi. 2018. Pengaruh Gaya Kepemimpinan dan Motivasi terhadap Kinerja Pegawai

pada Biro Umum dan Keuangan Universitas Lampung.

Cendekia, (2018), 12(1): 61 74. DOI: 10.30957/Cendekia.v12i1.463.

Handoko, T Hani, 2013, Manajemen Edisi Kedua, BPFE Gajah Mada, Yogyakarta.

Handoko, T Hani, 2012, Manajemen Personalia dan Sumberdaya Manusia Edisi Kedua, BPFE Gajah Mada, Yogyakarta.

Hasibuan, Malayu SP, 2007, Organisasi dan Motivasi, Bumi Akasara, Jakarta. Hasibuan. Malayu SP, 2007, Manajemen Sumber Daya Manusia, Bumi Aksara, Jakarta.

Historika, Novandri, 2012, Pengaruh Gaya Kepemimpinan dan Motivasi Kerja Terhadap Kinerja Pegawai pada Dinas Perhubungan Provinsi Kepulauan Riau. Tesis Magister Administrasi Publik Universitas Terbuka, Jakarta.

Irham. Fahmi, 2011, Manajemen Kinerja Teori dan Aplikasi, Alfabeta, Bandung.

Mangunegara, AA. Anwar Prabu, 2011, Manajemen Sumber Daya Manusia Perusahaan, Remaja Rosdakarya, Bandung.

Nawawi Uha. Ismail, 2013, Budaya Organisasi Kepemimpinan dan Kinerja, Kencana Prenadamedia Group, Jakarta.

Nazir, Mohammad, 1999, Metode Penelitian, Ghalia Indonesia, Jakarta.

Rencana Strategik Universitas Lampung Tahun 2011-2015, Bandar Lampung, 2012.

Rivai, Zainal, Veithzal dkk, 2014, Kepemimpinan dan Perilaku Organisasi, Raja Grafindo Persada, Jakarta.

Robbins. Stephen P, 2002, Prinsip Prinsip Perilaku Organisasi Edisi ke Lima, Alih Bahasa Halida dan Dewi Sartika, Erlangga, Jakarta.

Ruki, Achmad S, 2001, Sistem Manajemen Kinerja, Gramedia Pustaka Utama, Jakarta.

Stoner, James AF, Freeman. R. Edward, Gilbert JR. Daniel R, 2003, Manajemen Jilid II, Alih Bahasa Alexander Sindoro, PT. Indeks Gramedia Grup, Jakarta.

Sugandha, Dann, 1986, Kepemimpinan Di Dalam Administrasi, Sinar Baru, Bandung.

Sutikno, Sobry, 2014, Pemimpin dan Kepemimpinan Tips Praktis untuk Menjadi Pemimpin yang Diidolakan, Holistica, Lombok.

Sutrisno, Edy. 2011, Budaya Organisasi, Kencana Prenada Media Group, Jakarta. Sutrisno, Edy. 2013, Manajemen Sumber Daya Manusia, Kencana Prenada Media Group, Jakarta.

Thoha, Miftah, 2013, Kepemimpinan dalam Manajemen, Raja Grafindo Persada, Jakarta.

Wahjosumidjo, 1985, Kepemimpinan dan Motivasi, Ghalia Indonesia, Jakarta.

Yukl, Gary, 2009, Kepemimpinan Dalam Organisasi Edisi ke Empat, Alih Bahasa Budi Supriyanto, Indeks, Jakarta.

Yusmalinda, 2012, Pengaruh Motivasi dan Gaya Kepemimpinan terhadap Kinerja Pegawai pada Dinas Pendidikan Kabupaten Bungo, Tesis Magister Manajemen Universitas Terbuka, Jakarta. 